ISSN $0079-497 \mathrm{X}$

PROCEEDINGS OF THE PREHISTORIC SOCIETY

\title{
VOLUME 57, Part 1
}

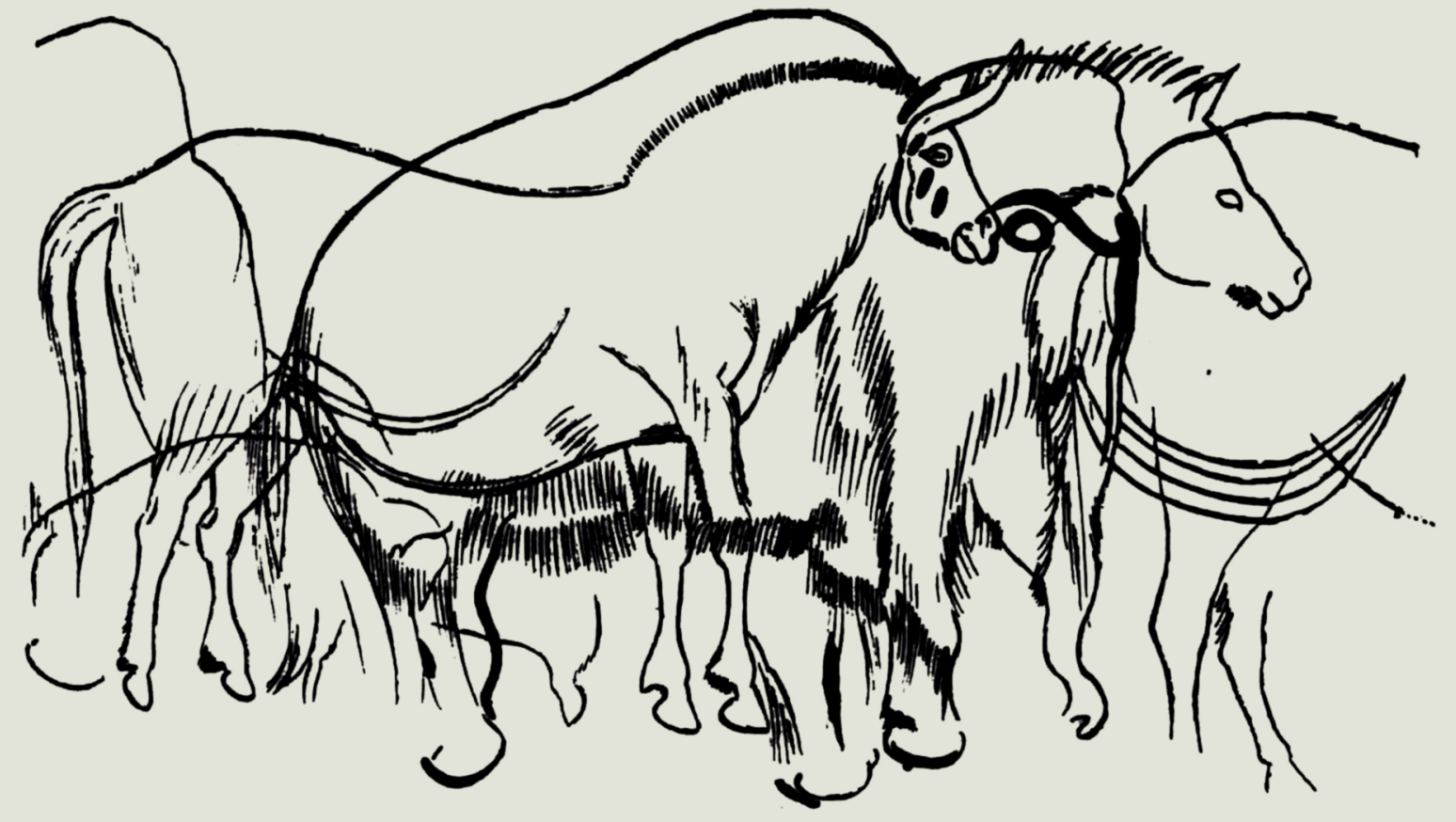




\section{THE PREHISTORIC SOCIETY}

THE SOCIETY promotes interest in prehistoric archaeology, encourages and engages in research, and disseminates knowledge of prehistory. Monthly meetings are held in London from October to March, with a full programme of northern lectures, now held in Newcastle. Other activities include an annual conference, field excursions and study tours, the last held both in Britain arid abroad. The Proceedings are published annually.

MEMBERSHIP. All applications for membership, subscriptions and changes of address should be sent to the Membership Secretary, The Prehistoric Society, The Museum Bookshop, 36 Great Russell Street, London WC I B 3 PP, England. Subscriptions are due, without reminder, on I January.

$\begin{array}{llll} & & 1991 & 1992 \text { onwards } \\ \text { SUBSCRIPTION RATES: } & \text { Individual } & £_{15} & £_{20} \\ & \text { Institutional } & £_{30} & £_{30} \\ & \text { Joint } & £_{17} & £_{22} \\ & \text { Retired and Student } & £_{9} & £_{9} \\ & \text { Retired, not receiving Proceedings } & £_{6} & £ 6\end{array}$

PROCEEDINGS. All communications concerning the publication of papers and notes in the Proceedings should be sent to Dr J. G. Evans, School of History and Archaeology, University of Wales College of Cardiff, PO Box 909, Cardiff CF I 3 XU. All contributors are encouraged to consult the Editors at an early stage in the preparation of papers and to obtain detailed instructions to contributors.

Books for review and periodicals for exchange should be sent to Dr A. W. R. Whittle at the same address.

Communications on other matters such as back numbers (see inside back cover for details), the insertion of leaflets, non-receipt of the Proceedings and permission to reproduce illustrative material from the Proceedings should be addressed to the Administrative Assistant (address below).

COPYRIGHT in the Proceedings rests with the Society. The Society will permit, without the need for specific authorization or payment of a fee, photocopying of

i. single copies of individual papers or sections of the Proceedings for the private use of individual researchers;

ii. single copies of individual papers or sections of the Proceedings for library reserve or short-term loan use;

iii. multiple copies of individual papers or sections of the Proceedings for teaching use, provided that such copies are taken for a non-profit-making institution for educational use within that institution only.

This consent does not extend to copying for general distribution, advertising or promotional purposes, the creation of new collective works or resale.

RESEARCH FUND. The Society hopes to make one or more awards from the Research Fund in 1992. Applications will be considered from members carrying out research into prehistoric archaeology anywhere in the world. Application forms are available from the Administrative Assistant, The Prehistoric Society, University College London, Institute of Archaeology, 3 I-34 Gordon Square, London wCI opY, England. The closing date for applications for 1992 is I January 1992. 


\title{
PROCEEDINGS OF THE PREHISTORIC SOCIETY
}

\author{
VOLUME 57, Part 1
}

ESSAYS IN PALAEOLITHIC ART

EDITED BY

A. J. LAWSON M.Sc., F.S.A. 
COUNCIL OF THE PREHISTORIC SOCIETY 1991

President

Vice-Presidents

Hon. Secretary

Hon. Treasurer

Assistant Treasurer

Hon. Editors

Hon. Meetings Secretaries

Hon. Public Relations Officer

Hon. Conservation

Co-Ordinator

Membership Secretary

Administrative Assistant

Council

Hon. Auditor
D. R. HARRIS, M.A., B.Litt., Ph.D., F.S.A.

R. J. MERCER, M.A., F.S.A., M.I.F.A.

P. C. WOODMAN, B.A., Ph.D., F.S.A., M.R.I.A.

R. J. BRADLEY, M.A., M.I.F.A., F.S.A.

T. C. Champion, M.A., D.Phil., F.S.A.

F. Healy, B.Sc.(Econ.), ph.D., F.S.A., M.I.F.A.

D. Thomson, M.A.

M. LANGDON, B.A.

J. G. Evans, B.Sc., Ph.D., F.S.A.

A. W. R. WhitTle, M.A., D.Phil., F.S.A.

B. J. COLES, M.A., F.S.A.

P. CHOWNE, Ph.D., M.I.F.A.

A. J. HiLl, C.B.E., M.A.

A. SAVILlE, B.A., F.S.A., M.I.F.A.

G. STEVENS

J. E. HARRIS, B.A., F.S.A.Scot.

R. H. BEWLEY, B.A., M.Phil., Ph.D., A.I.F.A.

J. C. Chapman, B.A., ph.D.

G. M. СоOK, B.A., D.Phil., F.S.A.

D. Fraser, M.A., Ph.D., M.I.F.A.

J. P. GARdiner, B.A., Ph.D., M.I.F.A., F.S.A.

H. S. GReEN, B.A., Ph.D., F.S.A.

F. M. GRIFFITH, B.A., M.I.F.A.

A. LEWISON

P. A. Mellars, M.A., Ph.D., SC.D., F.S.A., F.B.A.

B. S. OTTAWAY, M.A., Ph.D., F.S.A.Scot.

N. M. SHARPLES, M.A., M.I.F.A., F.S.A.Scot.

B. E. VyNER, M.A., Ph.D., F.S.A.

R. GARrod, M.A., Ph.D., F.C.A. 


\section{CONTENTS}

I Proceedings of the conference on Palaeolithic art, held in Oxford, 1989: introduction. By A. J. Lawson

2 The social context for European Palaeolithic art. By C. GAmble

3 The female image: a 'time-factored' symbol. A study in style and aspects of image use in the Upper Palaeolithic. By A. MARSHACK

4 Palaeolithic art and archaeology: the mobiliary evidence. By A. Sieveking

5 The representation of female figures in the Rhineland Magdalenian. By G. BosINSKI

6 Portable and wall art in the Volp caves, Montesquieu-Avantès (Ariège). By R. BÉGOUËN and J. ClotTeS

7 Reflections on the art of the Cave of Altamira. By F. B. DE Quirós

8 Pleistocene images outside Europe. By P. G. BAHN

9 Ecological interpretations of Palaeolithic art. By S. J. MitheN

Io Palaeolithic parietal art and its topographical context. By M. and A. EASTHAM

I I Elk and Ogopogo. Belief systems in the hunter-gatherer rock art of northern lands. By J. M. CoLES

I 2 Wrestling with analogy: a methodological dilemma in Upper Palaeolithic art research. By J. D. LEwIsWILLIAMS

I 3 Trends in the hunter-gatherer rock art of Western Europe and Australia. By R. LAYTON 